\title{
Durable and Environmentally Friendly Flame-Retardant Finish on Wool via Graft Copolymerization of Vinyl Phosphonic Acid
}

\author{
Farzad Mohaddes ${ }^{1,2}$, Saniyat Islam ${ }^{1}$ (D), Rajiv Padhye ${ }^{1}$, Lijing Wang 1,* (D) \\ 1 Department of Electrical and Computer Engineering, North Carolina State University, NC 27606, USA \\ 2 School of Fashion and Textiles, RMIT University, VIC 3056, Australia \\ * Correspondence: lijing.wang@ rmit.edu.au (L.W.);
}

Scopus Author ID 55850896900

Received: 5.04.2021; Revised: 15.06.2021; Accepted: 20.06.2021; Published: 12.08.2021

\begin{abstract}
A durable and environmentally friendly flame-retardant treatment process on wool via graft co-polymerization of vinyl phosphonic acid (VPA) was investigated. The influence of temperature, time, VPA, and catalyst on the grafting yield (GY) was studied. Employing response surface methodology, the grafting parameters were optimized, and the highest GY was achieved. Thermogravimetric studies showed a $3.86 \%$ increase in the remaining char ratio at $750^{\circ} \mathrm{C}$ for the wool fabric after graft co-polymerization of VPA. Flame retardancy of wool fabrics was evaluated with respect to their limiting oxygen indices (LOI) and the ease of ignition measurements. The sample with $8.1 \%$ GY exhibited a $35.89 \%$ increase in LOI and over a 3.66-fold increase in ignition time. The chemical structure of the grafted wool is proposed according to FTIR and ${ }^{31} \mathrm{P}$ Solid-state MAS NMR evidence. The presented flame-retardant finish process was deemed to be a green and durable substitute for the conventional, semi-durable, and non-environmentally friendly processes.
\end{abstract}

Keywords: flame retardant; fabric surface functionalization; environmental-friendly finish; wool; textile technology

(C) 2021 by the authors. This article is an open-access article distributed under the terms and conditions of the Creative Commons Attribution (CC BY) license (https://creativecommons.org/licenses/by/4.0/).

\section{Introduction}

Textiles are, in general, highly flammable, and fabrics are finished with reactive flameretardant (FR) systems to achieve the functional property. This could also be achieved via back coating of the substrate with polymer matrix by different compounds, e.g., polyacrylates, silicones, epoxides, polyurethanes, polyvinyl chloride, or composite FRs $[1,2]$. The rationale for choosing wool as the grafting carrier is its inherent low-flammability and further enhancement compared to the current systems available such as Zirpro® $[3,4]$. Few other methods [5-10] of treating wool materials were found in recent studies. The health concerns are even more escalated in situations where direct contact between chemically treated substrates and the human body is inevitable [11]. Therefore, the proposed FR treatment can serve as a safer alternative imposing minimal health risks when compared to Zirpro®-treated products.

Four major directives, namely Evaluation, Authorisation, and Restriction of Chemicals (REACH), Restriction of Hazardous Substances (RoHS), Substances of Very High Concern (SVHC), and the Waste Electric and Electronic Equipment (WEEE), have enforced the substitution of the halogenated flame retardants since 2005 due to their environmental and 
toxicological hazards [12-14]. Conventional Zirpro® finishes on wool are semi-durable, only durable to dry-cleaning, and based on the formation of coordination complexes between wool and hexahalogenated compounds or zirconates under acidic conditions $[3,4]$. Except for certain wool-blended products such as aircraft seat upholstery that only require dry cleaning, most machine washable wool products do not suffice for dry-cleaning. Many wool-blended products such as children's pajamas, firefighter's wool-blend shirt, etc., undergo frequent washing cycles over time. Therefore, an environmentally friendly process is necessary for machine-washable wool FR treatment.

Despite the formation of electrostatic bonds, acid/base reaction, and ionic bonds observed between FRs and wool, the formation of covalent bonds between FRs and wool has seldom been reported. For example, Cheng et al. [15], investigated the electrostatic addition of carboxyl/borate acid groups of the FR to the amino groups of the wool protein. After exhaustion in acidic conditions followed by 5 home laundry washing cycles, they reported a weight gain of $9.2 \mathrm{wt} \%$ and about $4 \%$ increase in limiting oxygen indices (LOI) for the treated fabrics. Mathur et al. [10], chemical addition of sulphamic acid and 1,2,3,4-Butane tetracarboxylic acid (BTCA) compounds to wool via pad-dry-cure was investigated and revealed evidence for probable acid/base reactions between the FR constituents and wool. In a similar study, Jiang et al. [16] synthesized ditrimethylolpropane biphosphoramide diethyleneamine and applied it to the woolen fabric via a pad-dry-cure process resulting in an LOI increase from $25.7 \%$ to $34.7 \%$ and a surge in residual char ratio under nitrogen purge from $28 \% \mathrm{wt} \%$ to $34 \% \mathrm{wt}$. In an interesting project by Liu et al. [17], wool was initially dyed with sodium copper chlorophyllin (SCC), and then the dyed wool was phosphorylated in a phosphoric acid/urea bath. During this process, the intumescent SCC and phosphoric acid species were connected to the amino groups in the peptide chain via ionic and hydrogen bonds, contributing to the elevated LOI of 36.5 compared to 25 for the untreated wool.

Phosphorus-based flame retardants such as phytic acid and chitosan ethoxyl urea phosphate [15] are found to be suitable replacements for halogenated flame retardants due to their comparatively negligible ecological impact during and after production [18]. Flame retardancy of organophosphorus materials arises from their thermal decomposition into water and phosphorus oxide that dehydrates the target polymer and liberates phosphoric acid. The generated phosphoric acid again produces more water and phosphorus oxides, which upon interacting with the polymeric substrate, form an insulating char barrier capable of suffocating the flame and hence improving flame retardancy of the base polymer [19-23]. In a study by Opwis et al. [24], vinyl phosphonic acid (VPA) was physically immobilized on different fabrics in the presence of a 50:50 photo-initiator mixture, ethanol, and a cross-linking agent, i.e., 1,3,5Triazine-2,4,6(1H,3H,5H)-trion,1,3,5-tri-2-propenyl under UV irradiation. The resulting fabrics showed satisfactory flame retardancy before washing. However, $50 \% \cdot \mathrm{w} / \mathrm{w}$ of the reaction mixture was washed off from the fabric after the first home laundry cycle. In a similar work, Cheng et al. [15] introduced a bio-resourced organophosphorus compound (phytic acid) to chitosan polyelectrolyte to form an intumescent and char-forming composite could be deposited on wool fibers. The unwashed coated fabric exhibited a high LOI of 33.3, which dwindled to about 28 after undergoing 10 laundering cycles. The adverse effect of laundering cycles on the FR properties as well as the anticipated poor wearability and breathability due to the significant add-on weight of $9-20 \% \cdot \mathrm{w} / \mathrm{w}$ are of the drawbacks of the suggested method. The application of vinyl-containing monomers onto wool dates back to the 1960s [25]; 
however, no investigation on graft co-polymerization of VPA has been reported on wool to date.

Compared with aliphatic diacyl peroxide initiators, persulphates exhibited slower dissociation rates and increased the chance of monomer diffusion at temperatures around $80{ }^{\circ} \mathrm{C}$. Moreover, the use of persulphates suppresses the formation of undesirable homopolymerization in the vicinity of the polymeric backbone [26]. As the use of persulphates in grafting vinyl monomers onto wool has been previously reported [27], potassium persulphate was chosen as the graft co-polymerization initiator.

A durable, efficient, and environmentally-friendly flame-retardant finish on wool through co-polymerization of VPA has been presented in this study. The formation of new bonds between wool and VPA was investigated by Fourier transform infrared (FT-IR) and ${ }^{31} \mathrm{P}$ solid-state magic-angle nuclear magnetic resonance $\left({ }^{31} \mathrm{P}\right.$ solid-state NMR) spectroscopy. The grafted wool's morphology and elemental make-up were evaluated using Scanning Electron Microscopy (SEM) and Energy-Dispersive X-ray (EDX) spectroscopy. Crystallographic data were collected via Small Angle X-ray Scattering (SAXS). Flammability and thermal properties of the grafted specimens were determined via thermogravimetric analysis (TGA), thermogravimetric derivative (TGD), ease of ignition, and Limiting Oxygen Index (LOI) measurements. Response surface methodology (RSM) was adopted to optimize the grafting process for achieving the highest obtainable graft yield $(G Y)$.

\section{Materials and Methods}

\subsection{Materials.}

Woven wool fabric $\left(150 \mathrm{~g} \cdot \mathrm{m}^{-2}\right)$ with plain structure was obtained from Macquarie Textiles, Australia. VPA solution (90\%) of VPA, sulphuric acid (98\%), and potassium persulphate (99\%) were purchased from Merck, Australia. All the reagents were used without further extraction or purification.

\subsection{Pre-and post-grafting wash.}

In order to remove the contaminants and ungrafted fragments, undyed wool fabrics were washed before and after graft-copolymerization with $2 \mathrm{~g} \cdot \mathrm{L}^{-1}$ non-ionic surfactant at $50{ }^{\circ} \mathrm{C}$ and a liquor to goods ratio of $\mathrm{L}: \mathrm{G}=100: 1$ for $1 \mathrm{~h}$ using an Atlas Industrial Launder-Ometer (Model LHD-EF-B5, USA). Each fabric underwent at least three standard washing cycles, and the values reported in the subsequent sections were the mean values of at least three statistically similar values within $95 \%$ of confidence to ensure both data reproducibility and durability of the FR treatment. The washed fabrics were thoroughly rinsed, Soxhlet-extracted with acetone for $12 \mathrm{~h}$, and conditioned for $72 \mathrm{~h}$ at $20^{\circ} \mathrm{C}$ and relative humidity of $65 \%$. pH measurements were carried out to assess the thoroughness of the post-grafting wash for each grafted sample. To do so, $50 \mathrm{~mL}$ of distilled water was thermostated at $60^{\circ} \mathrm{C}$ and stirred along with each sample at $150 \mathrm{rpm}$ for $3 \mathrm{~h}$. The sample was then removed, and the $\mathrm{pH}$ of the water was measured. The samples with no acidity traces were chosen for other tests.

\subsection{Influence of the grafting variables on $G Y$.}

Using a Thermoline Scientific Shaking Water Bath (Model BT-150, Australia), wool fabric pieces of $10 \mathrm{~cm} \times 10 \mathrm{~cm}$ were separately mixed with reagents at $150 \mathrm{RPM}$ and $\mathrm{L}: \mathrm{G}=$ 
20:1 in hermetically sealed stainless steel containers. In order to evaluate the influence of each variable on $G Y$, the effects of VPA $(0.063-0.500 \mathrm{M})$ and $\mathrm{H}_{2} \mathrm{SO}_{4}(0.000-1.030 \mathrm{M})$ concentrations, grafting time $(0.5 \mathrm{~h}, 1 \mathrm{~h}, 2 \mathrm{~h}, 3 \mathrm{~h}$, and $6 \mathrm{~h})$, and temperature $\left(60{ }^{\circ} \mathrm{C}, 70{ }^{\circ} \mathrm{C}\right.$, and $80{ }^{\circ} \mathrm{C}$ ) were separately investigated. The graft yield of the treated fabric GY can be calculated using Equation 1 [28]:

$$
G Y=\frac{W_{g}-W_{0}}{W_{0}} \times 100
$$

where, $\mathrm{W}_{0}$ is the initial sample weight, $\mathrm{W}_{\mathrm{g}}$ the grafted sample weight.

\subsection{Mathematical modeling, statistical evaluation, and numerical optimization.}

Using the design expert 10 platform, response surface methodology (RSM) was employed to determine the significance of the grafting variables and develop a mathematical model according to the experimental data shown in Table 1. Analysis of variance (ANOVA) and numerical optimization results was considered to examine the adequacy of the devised model and maximize the theoretical GY, respectively.

\subsection{Fourier Transform Infra-Red (FTIR) spectroscopy.}

Chemical characterization of grafted and ungrafted wool fabrics was carried out using a PerkinElmer 400 FTIR-FTNIR spectrometer in a range between $4000 \mathrm{~cm}^{-1}$ and $650 \mathrm{~cm}^{-1}$.

\section{6. ${ }^{31} \mathrm{P}$ Solid-state Magic-Angle Nuclear Magnetic Resonance $\left({ }^{31} \mathrm{P}\right.$ Solid-state NMR).}

${ }^{31} \mathrm{P}$ Solid-state NMR spectra were acquired on a $500 \mathrm{MHz}$ Agilent DD2 console equipped with a triple resonance Solid-state MAS probe. Using an 'onepul' pulse sequence with 4-1000 accumulations, spectra were acquired at a $10 \mathrm{kHz}$ spin rate and externally referenced to hexamethylbenzene (methyl singlet referenced to $17.43 \mathrm{ppm}$ ). Both grafted and ungrafted wool fabrics were loaded into $4 \mathrm{~mm}$ rotors while the rotation frequencies were set at $10 \mathrm{kHz}$. Phosphorous spectra were acquired using 2500 scans with an acquisition time of $50 \mathrm{~ms}$ and a delay of $10 \mathrm{~s}$.

\subsection{Scanning Electron Microscopy (SEM) and Energy Dispersive X-Ray spectroscopy (EDX).}

SEM imaging was performed using an FEI Quanta200 (tungsten filament) equipped with an Oxford Instruments Si (Li) X-ray detector and an X-MaxN20 spectrometer for EDX. The specimens were coated with carbon or gold to reduce charging artifacts when used in SEMEDX or SEM imaging, respectively, using an SPI-Module Sputter Coater (model 11430, USA). SEM-EDX elemental analysis was carried out on the gold-coated samples at $25 \mathrm{kV}$ while including the carbon in the final elemental make-up.

\subsection{Small Angle X-Ray Scattering (SAXS).}

Crystallographic evaluation of samples was performed using a Bruker AXS D4 Endeavour system equipped with a Lynxeye linear strip detector with $\mathrm{Cu}-\mathrm{K} \alpha$ radiation at 40 $\mathrm{kV}$ and $40 \mathrm{~mA}$. Samples were tested between 0 and 90 degrees 2 theta, and the scattering patterns were collected. 


\subsection{Thermogravimetry.}

Thermogravimetric Analysis (TGA) and thermogravimetric derivative (TGD) were carried out on the grafted and ungrafted wool samples using a PerkinElmer TGA 7 thermogravimetric analyzer between $30^{\circ} \mathrm{C}$ and $750{ }^{\circ} \mathrm{C}$ at $10{ }^{\circ} \mathrm{K} \cdot \mathrm{min}^{-1}$ under nitrogen purge of $20 \mathrm{~mL} \cdot \mathrm{min}^{-1}$. Each sample weighed between $4 \mathrm{mg}$ and $7 \mathrm{mg}$.

Table 1. Experimental parameters and $G Y$ values used for response surface methodology.

\begin{tabular}{|c|c|c|c|c|c|}
\hline Run & $\mathrm{A}:[$ Monomer] $(\mathrm{M})$ & B:Temperature $\left({ }^{\circ} \mathrm{C}\right)$ & C:[Sulphuric Acid] (M) & D:Time (min) & $G Y \%$ \\
\hline 1 & 0.063 & 50 & 0.00 & 30 & 0.4 \\
\hline 2 & 0.250 & 50 & 0.00 & 30 & 1.3 \\
\hline 3 & 0.063 & 50 & 0.00 & 60 & 0.6 \\
\hline 4 & 0.250 & 50 & 0.00 & 60 & 1.6 \\
\hline 5 & 0.250 & 50 & 0.00 & 90 & 0.7 \\
\hline 6 & 0.063 & 50 & 0.82 & 30 & 0.7 \\
\hline 7 & 0.250 & 50 & 0.82 & 30 & 2.4 \\
\hline 8 & 0.063 & 50 & 0.82 & 60 & 0.9 \\
\hline 9 & 0.250 & 50 & 0.82 & 60 & 2.9 \\
\hline 10 & 0.250 & 50 & 0.82 & 90 & 3.1 \\
\hline 11 & 0.063 & 80 & 0.00 & 30 & 1.0 \\
\hline 12 & 0.250 & 80 & 0.00 & 30 & 3.9 \\
\hline 13 & 0.063 & 80 & 0.00 & 60 & 1.4 \\
\hline 14 & 0.250 & 80 & 0.00 & 60 & 4.2 \\
\hline 15 & 0.250 & 80 & 0.00 & 90 & 4.3 \\
\hline 16 & 0.063 & 80 & 0.82 & 30 & 1.6 \\
\hline 17 & 0.250 & 80 & 0.82 & 30 & 4.4 \\
\hline 18 & 0.063 & 80 & 0.82 & 60 & 2.2 \\
\hline 19 & 0.250 & 80 & 0.82 & 60 & 7.9 \\
\hline 20 & 0.250 & 80 & 0.82 & 90 & 7.9 \\
\hline 21 & 0.063 & 90 & 0.00 & 30 & 0.8 \\
\hline 22 & 0.250 & 90 & 0.00 & 30 & 3.5 \\
\hline 23 & 0.063 & 90 & 0.00 & 60 & 0.6 \\
\hline 24 & 0.250 & 90 & 0.00 & 60 & 3.1 \\
\hline 25 & 0.250 & 90 & 0.00 & 90 & 2.7 \\
\hline 26 & 0.063 & 90 & 0.82 & 30 & 1.3 \\
\hline 27 & 0.250 & 90 & 0.82 & 30 & 4.0 \\
\hline 28 & 0.063 & 90 & 0.82 & 60 & 1.7 \\
\hline 29 & 0.250 & 90 & 0.82 & 60 & 5.8 \\
\hline
\end{tabular}

\subsection{Ease of ignition.}

The ease of ignition for vertically oriented specimens was determined for both grafted and ungrafted fabrics in accordance with a slight modification of standard test method ISO 6940:2004 (Textile fabrics - Burning behavior - Determination of ease of ignition of vertically oriented specimens). Size variation of the test specimen $(10 \times 10) \mathrm{cm}^{2}$ was adopted due to the sample size available to accommodate the machine setting and all the tests in the study. In this test, a horizontal fire-gun with a pre-adjusted flame length was aimed perpendicularly at the vertically mounted textile for a specific time, and the mean of the time required for either self-extinguishment or ignition was determined.

\subsection{Limiting Oxygen Index (LOI).}

The higher the values of this index, the more flame retardant the specimen. LOI values 
of grafted and ungrafted specimens were determined using an Oxygen Index Apparatus (Fire Testing Technology Ltd., England) according to the standard test method ASTM D2863-13 [29].

\section{Results and Discussion}

\subsection{Influence of grafting variables on $G Y$.}

Figure 1 shows the effect of each variable (temperature, time, and concentration of VPA and sulphuric acid) while considering the other variables constant. Tests were carried out in quintuplicates to ensure data reproducibility. GY increased as the VPA concentration increased from $0.063 \mathrm{M}$ and reached its maximum $(\mathrm{GY}=7.9 \%)$ at $0.250 \mathrm{M}$. GY then reached a plateau while increasing the VPA concentration up to $0.313 \mathrm{M}$. Any further increase in VPA concentration resulted in a decline in GY. This decline is a result of an acceleration of the homopolymerization reaction in contrast to the graft co-polymerization in the immediacy of the polymeric backbone over a certain VPA concentration [30].

The most common impacts of sulphuric acid on polymers are fibrillation and swelling of the intra-crystallite structure, facilitating further diffusion of VPA into the substrate [30]. The GY increased with increasing sulphuric acid concentration and reached its maximum $(\mathrm{GY}=7.9 \%)$ at $0.820 \mathrm{M}$. Any further increase in acid concentration up to $1 \mathrm{~mol} \cdot \mathrm{L}^{-1} \mathrm{did}$ not increase GY significantly.

Adjusting the temperature and time of grafting can facilitate VPA diffusion into the polymeric structure, increase the number of effective contacts between VPA molecules and polymeric chains, and raise the number of free radicals [26,30]. GY was elevated from $2.9 \%$ to $7.9 \%$ when the temperature increased from $50{ }^{\circ} \mathrm{C}$ to $80{ }^{\circ} \mathrm{C}$. At temperatures above $80{ }^{\circ} \mathrm{C}$, GY started to decrease, which can be due to chain scission and overall structural collapse across the keratin structure. The maximum GY of $7.9 \%$ was achieved after 60 min while upholding the same experimental conditions $\left([\mathrm{VPA}]=0.250 \mathrm{M},\left[\mathrm{K}_{2} \mathrm{~S}_{2} \mathrm{O}_{8}\right]=0.022 \mathrm{M},\left[\mathrm{H}_{2} \mathrm{SO}_{4}\right]=0.820 \mathrm{M}\right.$, $80{ }^{\circ} \mathrm{C}$, and $\mathrm{L}: \mathrm{G}=20: 1$ ). Any further elongation in the grafting process was ineffective to $\mathrm{GY}$.
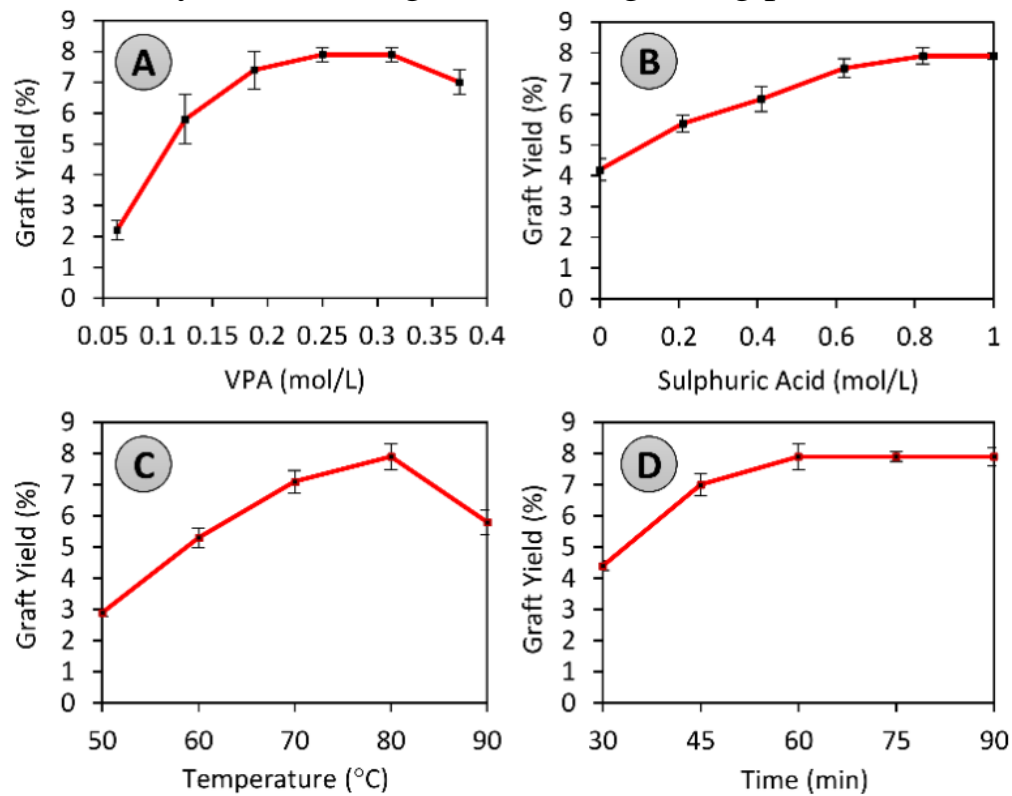

Figure 1. Influence of individual variables on the $G Y$. (A) Effect of [VPA]: $\mathrm{K}_{2} \mathrm{~S}_{2} \mathrm{O}_{8}(0.022 \mathrm{M}), \mathrm{H}_{2} \mathrm{SO}_{4}$ $(0.820 \mathrm{M}), 120 \mathrm{~min}, 80^{\circ} \mathrm{C}, \mathrm{L}: \mathrm{G}=20: 1$; (B) Effect of $\left[\mathrm{H}_{2} \mathrm{SO}_{4}\right]$ : VPA $(0.250 \mathrm{M}), \mathrm{K}_{2} \mathrm{~S}_{2} \mathrm{O}_{8}(0.022 \mathrm{M}), 120 \mathrm{~min}$, $80{ }^{\circ} \mathrm{C}, \mathrm{L}: \mathrm{G}=20: 1$; (C) Effect of temperature: VPA (0.250 M), $\mathrm{K}_{2} \mathrm{~S}_{2} \mathrm{O}_{8}(0.022 \mathrm{M}), \mathrm{H}_{2} \mathrm{SO}_{4}(0.820 \mathrm{M}), 120 \mathrm{~min}$,

$\mathrm{L}: \mathrm{G}=20: 1 ;\left(\right.$ D) Effect of time: VPA $(0.250 \mathrm{M}), \mathrm{K}_{2} \mathrm{~S}_{2} \mathrm{O}_{8}(0.022 \mathrm{M}), \mathrm{H}_{2} \mathrm{SO}_{4}(0.820 \mathrm{M}), 80{ }^{\circ} \mathrm{C}, \mathrm{L}: \mathrm{G}=20: 1$. 


\subsection{Mathematical modeling and statistical analysis.}

Table 2 shows the upper and lower limits associated with each factor used in RSM. The natural quadratic model was initially fitted to the experimental data shown in Table 1 through a second-order polynomial function of the Box-Behnken design. As the used model was aliased by the second power of the VPA [monomer] and [sulphuric acid], both aliased terms (hereby assigned as $\mathrm{A}^{2}$ and $\mathrm{C}^{2}$ ) were eliminated from the model. The reduced quadratic model was then fitted to the experimental data, and no aliases were detected. Figure 2 shows the 3D RSM plot of the reduced quadratic model.

Table 2. Range of variables used in RSM.

\begin{tabular}{c|c|c|c|c} 
Factor & Name & Unit & Lower Limit & Upper Limit \\
\hline A & Monomer & $\mathrm{M}$ & 0.063 & 0.250 \\
\hline B & Temperature & ${ }^{\circ} \mathrm{C}$ & 50 & 90 \\
\hline C & Sulphuric Acid & $\mathrm{M}$ & 0 & 0.82 \\
\hline D & Time & $\min$ & 30 & 90
\end{tabular}

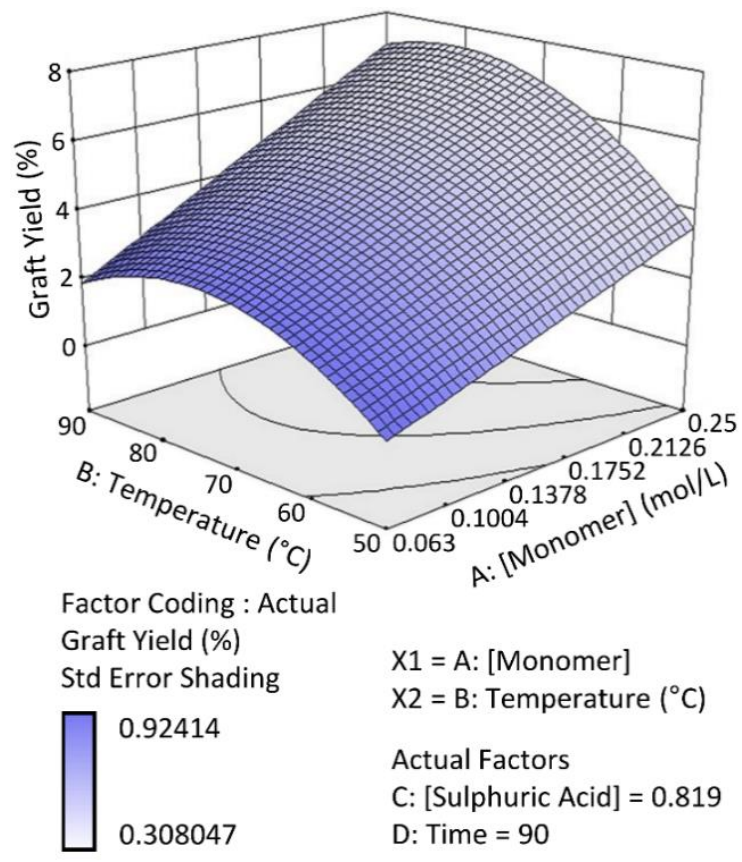

Figure 2. 3D RSM plot of the reduced quadratic model based on the Box-Behnken design.

Equation 2 shows the final fitted model with a corresponding R-squared value of 0.948 in terms of coded factors.

$$
\begin{aligned}
& \text { Graft Yield }=3.7745+(1.6100 \times A)+(0.8931 \times B)+(1.1050 \times C)-(0.5696 \times D) \\
& +(0.4903 \times A \times B)+(0.2650 \times A \times C)+(0.5500 \times A \times D)+(0.2008 \times B \times C)+ \\
& (0.4202 \times B \times D)+(0.8602 \times C \times D)-\left(1.6365 \times B^{2}\right)-\left(1.0872 \times D^{2}\right)
\end{aligned}
$$

where $\mathrm{A}, \mathrm{B}, \mathrm{C}$, and $\mathrm{D}$ represent VPA monomer concentration $(\mathrm{M})$, temperature $\left({ }^{\circ} \mathrm{C}\right)$, sulphuric acid concentration $(\mathrm{M})$, and time (min), respectively.

The adequacy of the response surface reduced the quadratic model, and the applied terms were verified via statistical analysis of variance (ANOVA), as shown in Table 3.

Table 3. Analysis of variance for the reduced quadratic model [partial sum of squares - type III].

\begin{tabular}{l|c|c|c|c|c} 
Source & Sum of Squares & df & Mean Square & F Value & p-value Prob > F \\
\hline Model* & 110.60 & 12 & 9.22 & 24.28 & 0.000 \\
\hline A-[Monomer] & 12.35 & 1 & 12.35 & 32.54 & 0.000 \\
\hline B-Temperature & 6.47 & 1 & 6.47 & 17.04 & 0.001 \\
https://biointerfaceresearch.com/
\end{tabular}




\begin{tabular}{|c|c|c|c|c|c|}
\hline Source & Sum of Squares & df & Mean Square & F Value & p-value Prob $>$ F \\
\hline C-[Sulphuric Acid] & 14.68 & 1 & 14.68 & 38.68 & 0.000 \\
\hline D-Time & 0.20 & 1 & 0.20 & 0.53 & 0.476 \\
\hline $\mathrm{AB}$ & 4.44 & 1 & 4.44 & 11.69 & 0.004 \\
\hline $\mathrm{AC}$ & 1.80 & 1 & 1.80 & 4.73 & 0.045 \\
\hline $\mathrm{AD}$ & 0.81 & 1 & 0.81 & 2.13 & 0.164 \\
\hline $\mathrm{BC}$ & 0.82 & 1 & 0.82 & 2.17 & 0.160 \\
\hline $\mathrm{BD}$ & 0.76 & 1 & 0.76 & 2.00 & 0.177 \\
\hline $\mathrm{CD}$ & 4.38 & 1 & 4.38 & 11.54 & 0.004 \\
\hline $\mathrm{B}^{2}$ & 8.70 & 1 & 8.70 & 22.92 & 0.000 \\
\hline $\mathrm{D}^{2}$ & 0.89 & 1 & 0.89 & 2.34 & 0.146 \\
\hline Residual & 6.07 & 16 & 0.38 & & \\
\hline Cor Total & 116.67 & 28 & & & \\
\hline
\end{tabular}

\subsection{Grafting process optimization.}

The Design Expert 10 software package was employed for numerical optimization of experimental parameters to maximize the $G Y$ while considering the following premises concluded from Section 3.1:

(1) Due to the severe degradation of wool at temperatures above $80{ }^{\circ} \mathrm{C}$, the permissible temperature range was chosen to be $50-80{ }^{\circ} \mathrm{C}$.

(2) Given the ineffectiveness of time on grafting beyond the 60-min mark, lower- and upper-time limits were chosen to be $30 \mathrm{~min}$ and $60 \mathrm{~min}$, respectively.

(3) Due to the undesirable homopolymerization at VPA concentrations above $0.313 \mathrm{M}$, the effective range for VPA concentration was determined to be $0.063-0.250 \mathrm{M}$.

(4) By applying premises 1, 2, and 3, the maximum sulphuric acid concentration within the valid range for coded values of the applied design was determined by the software to be $2.400 \mathrm{M}$.

As shown in Figure 3, the maximum hypothetical GY of $8.22 \%$ with the desirability of $100.0 \%$ was achieved at VPA $(0.250 \mathrm{M})$, sulphuric acid $(1.360 \mathrm{M})$, temperature $\left(80{ }^{\circ} \mathrm{C}\right)$, and time $(60 \mathrm{~min})$. The summary of the optimization limits is shown in Table 4 . The suggested optimal conditions were applied experimentally, and a maximum GY of $8.1 \%$ was achieved. Any further increase above the suggested sulphuric acid concentration $(1.360 \mathrm{M})$ did not yield higher or lower GY.
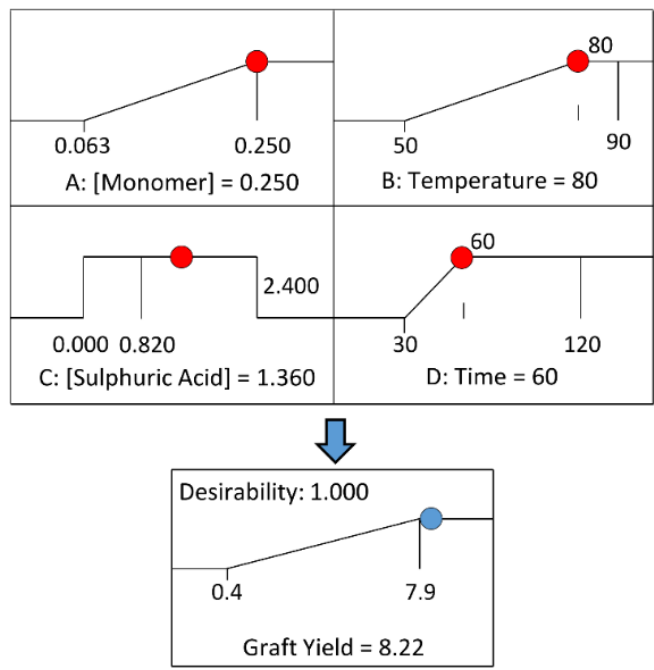

Figure 3. Ramp illustration of the optimized solution with $100.0 \%$ desirability. 
Table 4. Optimization constraints.

\begin{tabular}{l|c|c|c} 
Name & Goal & Lower Limit & Upper Limit \\
\hline A: [Monomer] & maximize & 0.063 & 0.250 \\
\hline B: Temperature & maximize & 50 & 80 \\
\hline C: [Sulphuric Acid] & is in range & 0 & 2.40 \\
\hline D: Time & maximize & 30 & 60 \\
\hline Graft Yield \% & maximize & 0.4 & 7.9
\end{tabular}

\subsection{Mechanism of grafting.}

The grafting mechanism of VPA onto wool is similar to graft-copolymerization of other vinyl monomers such as methyl methacrylate [27]. Initially, potassium persulphate as the free radical initiator is activated by heat and sulphuric acid and attacks the wool backbone to form macro-wool radicals. The wool radicals then attack the VPA resulting in graft initiation. The termination of graft co-polymerization may be due to any of the following reasons: undesirable interaction between wool and the primary radicals, a mutual combination of growing grafted chains on different backbones, and/or excessive amounts of primary radicals in the system.

\subsection{FTIR spectroscopy.}

FTIR's possibilities of VPA grafting through the terminal methyl groups and the secondary amides in the wool chemical structure were examined. Figure 4 shows the FTIR spectra of ungrafted wool, grafted wool, and VPA (90\%). Absorption bands at $1087 \mathrm{~cm}^{-1}$, $1246 \mathrm{~cm}^{-1}$, and $1402 \mathrm{~cm}^{-1}$ in the wool spectrum are attributed to $\mathrm{C}-\mathrm{C}, \mathrm{C}-\mathrm{NH}$, and $\mathrm{COO}-$, respectively [31]. Vibrational peaks at $1515 \mathrm{~cm}^{-1}$ and $1630 \mathrm{~cm}^{-1}$ are associated with secondary amide $\mathrm{N}-\mathrm{H}$ bending vibrations and amide $\mathrm{C}=\mathrm{O}$ stretching vibrations, respectively [32]. The single absorption band at $3275 \mathrm{~cm}^{-1}$ refers to the $-\mathrm{NH}$ stretching vibration of the secondary amide [32].

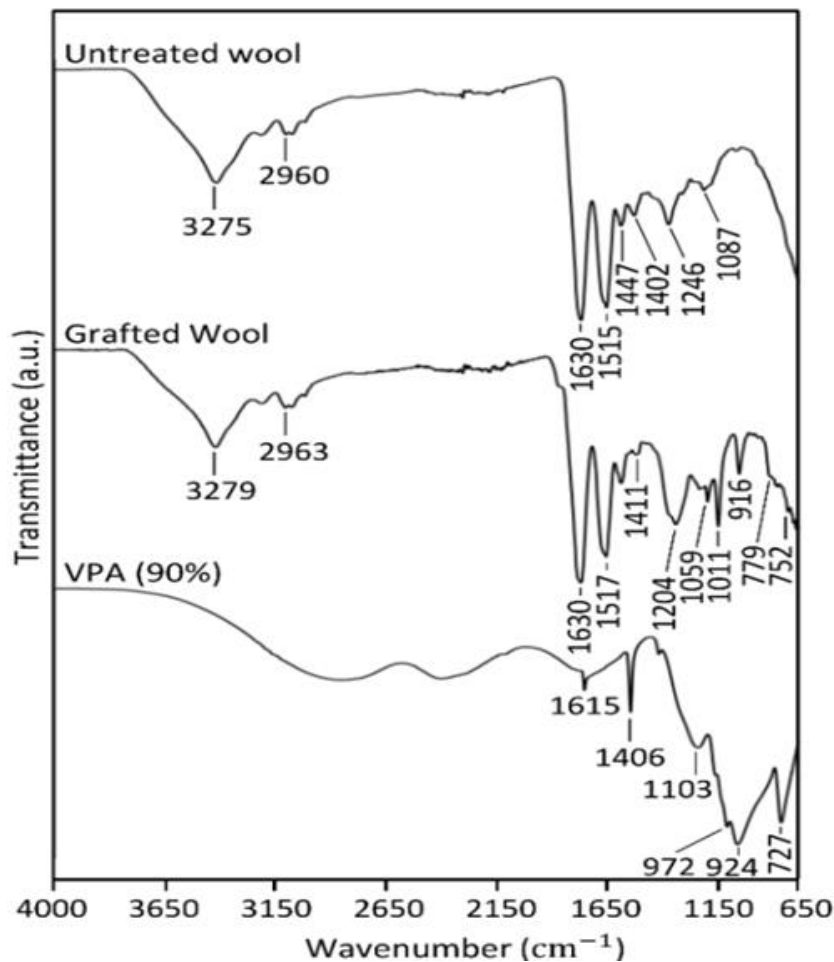

Figure 4. FTIR spectra of ungrafted wool, grafted wool, and VPA (90\%). 
VPA (90\%) presents several characteristic absorption peaks. The band at $727 \mathrm{~cm}^{-1}$ denotes the $\mathrm{P}-\mathrm{O}$ stretching vibration [32]. The band at $924 \mathrm{~cm}^{-1}$ corresponds to the $\mathrm{P}-\mathrm{OH}$ stretching vibration within the phosphonic group at $\mathrm{pH}$ around 5 [33]. The peak at $972 \mathrm{~cm}^{-1}$ and the broadband between $1103 \mathrm{~cm}^{-1}$ and $1230 \mathrm{~cm}^{-1}$ denote the $\mathrm{P}=\mathrm{O}$ absorption [34]. The peak at $1615 \mathrm{~cm}^{-1}$ stands for the vinyl $\mathrm{C}=\mathrm{C}$ stretching vibration [32]. The absorption bands at $752 \mathrm{~cm}^{-1}$ and $916 \mathrm{~cm}^{-1}$ correspond to $\mathrm{P}-\mathrm{O}$ and $\mathrm{P}-\mathrm{OH}$ stretching vibrations in the grafted wool spectrum, respectively $[32,33]$. The band at $1204 \mathrm{~cm}^{-1}$ denotes the $\mathrm{P}=\mathrm{O}$ stretching vibration in the phosphonate group [35]. The strong peak at $1630 \mathrm{~cm}^{-1}$ is attributed to the amide carbonyl group in the wool chemical structure.

The lack of a characteristic sharp tertiary amide band at around $2970 \mathrm{~cm}^{-1}$ and the presence of a secondary amide $\mathrm{N}-\mathrm{H}$ stretching vibration at $3279 \mathrm{~cm}^{-1}$ in the grafted wool spectrum dismiss the possibility of abstraction of hydrogen atoms from the amide groups present in the wool keratin structure. On the other hand, asymmetric decomposition of potassium persulphate caused by thermally assisted acid-catalyzed reactions yields free-radical species, which by abstracting a hydrogen atom from wool terminal methyl and/or middle-chain methylene groups may create active sites for grafting [30,36].

\section{6. ${ }^{31} P$ MAS Solid-state NMR.}

Figure 5 shows the ${ }^{31} \mathrm{P}$ MAS Solid-state NMR spectra of VPA-grafted and ungrafted wool. As anticipated, no peaks attributed to phosphorus-containing moieties were detected in the ${ }^{31}$ P NMR Solid-state NMR spectrum of the ungrafted wool. On the other hand, grafted wool spectrum exhibited two characteristic peaks associated with phosphonate and triphosphate groups at about $20 \mathrm{ppm}$ and $6 \mathrm{ppm}$, respectively [37,38]. As the conversion of phosphonates to phosphates has been previously reported [37], it can be concluded that the graft copolymerization of VPA onto wool can occur through both phosphonate and triphosphate groups.

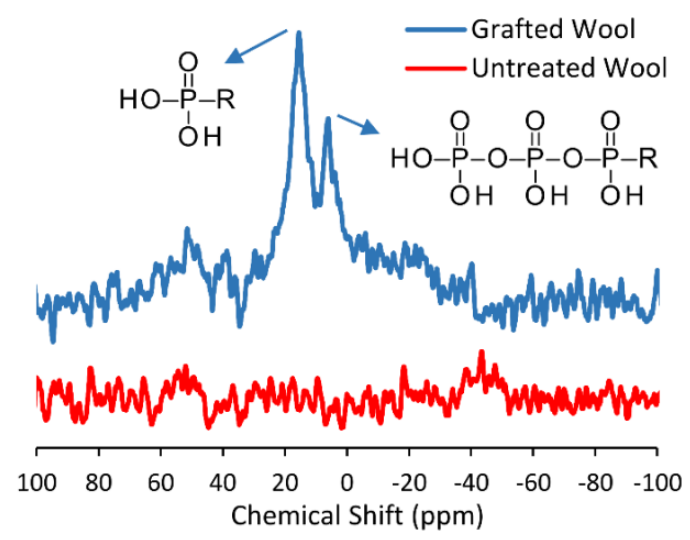

Figure 5. ${ }^{31} \mathrm{P}$ MAS Solid-state NMR spectra of VPA-grafted and ungrafted wool.

Figure 6 shows the proposed chemical structure of the VPA-grafted wool based on the spectroscopic analyses reported in this work (Sections 3.5 and 3.6) and a model suggested by Hutchinson et al. [39]. Terminal methylene and fatty acid zones were considered as potential sites at which grafting may take place. On the contrary, other active sites such as radicalized methylene or methyl groups within the cross-linked protein matrix are deemed to have lower chances of participating in graft co-polymerization due to steric and electrostatic hindrances [39]. 


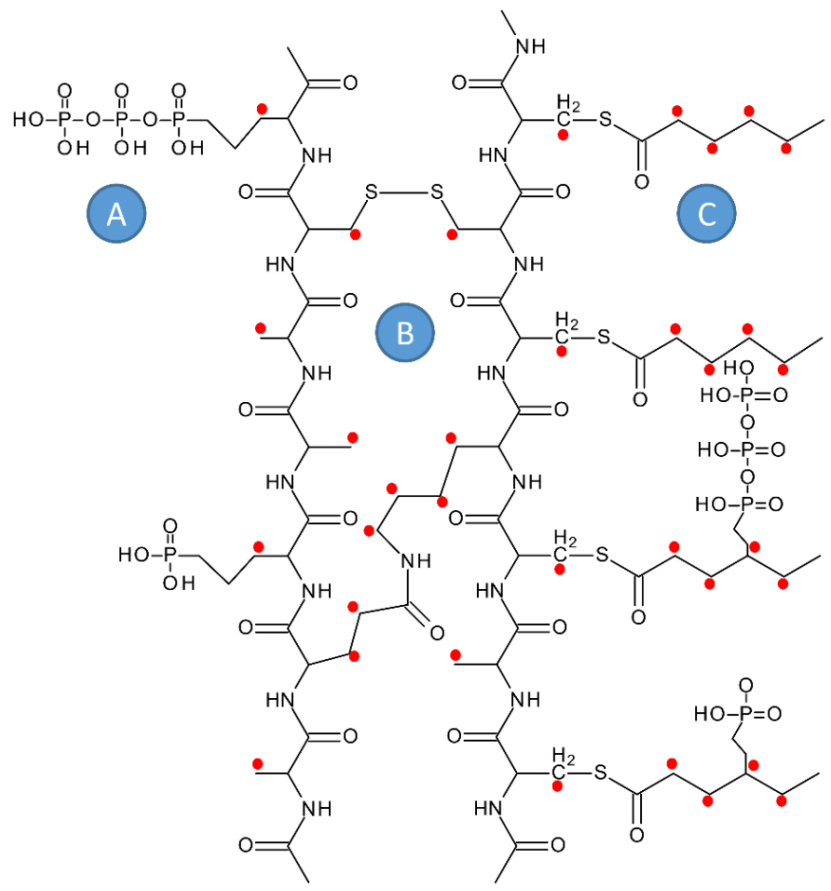

Figure 6. Proposed wool chemical structure after graft co-polymerization of VPA; A: Free terminal methylene zone; B: Cross-linked protein matrix comprising disulfide bonds, isopeptide bridges, and wool amino acids; C:

Fatty acids zone; Red dots are indicative of potential sites for graft co-polymerization.

\subsection{SEM and SEM-EDX.}

Figure 7 shows the SEM micrographs and the SEM-EDX elemental composition of the grafted $(\mathrm{GY}=8.1 \%)$ and ungrafted wool specimens (Both figures are at $1500 \mathrm{X}$ magnifications). Figure 7B shows the wool fabric grafted with phosphonate and triphosphate groups (mentioned in Section 3.6) after washing. The appearance of the phosphorus characteristic band at $2.3 \mathrm{kV}$ in the grafted wool EDX spectrum verified the phosphorylation of the wool after the graft copolymerization. An increase of $1.92 \% \cdot \mathrm{w} / \mathrm{w}$ in phosphorus content after grafting denotes higher flame-retardant properties. This is due to the formation of carbonaceous char responsible for preventing further thermal degradation of the wool after combustion $[19,40]$.

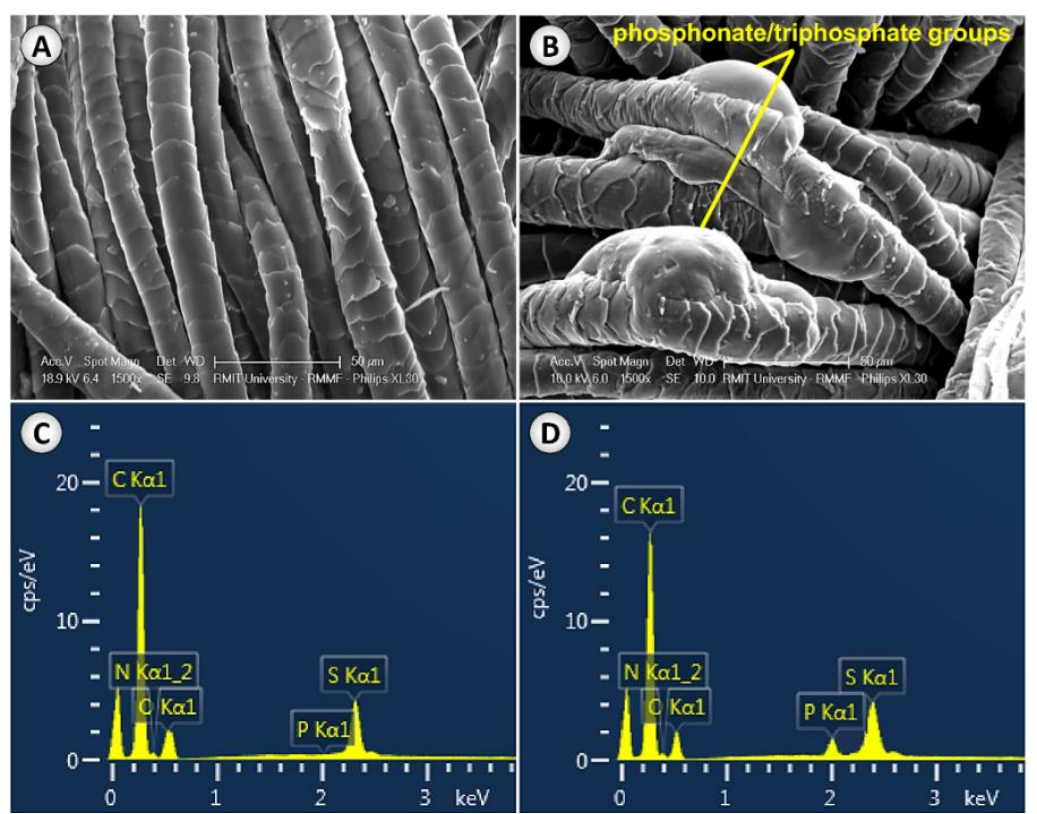

Figure 7. SEM micrographs and SEM-EDX patterns of the ungrafted (A and $\mathbf{C})$ and VPA-grafted (B and $\mathbf{D})$ wool $(G Y=8.1 \%)$. 
Table 5 shows the weight contribution of the chosen elements $(\mathrm{C}, \mathrm{O}, \mathrm{N}, \mathrm{P}, \mathrm{S})$ in wool specimens before and after grafting.

Table 5. SEM-EDX elemental measurements of VPA-grafted and ungrafted wool.

\begin{tabular}{l|c|c|c|c|c} 
Sample & $\begin{array}{c}\mathrm{C} \\
(\% \cdot \mathrm{w} / \mathrm{w})\end{array}$ & $\begin{array}{c}\mathrm{O} \\
(\% \cdot \mathrm{w} / \mathrm{w})\end{array}$ & $\begin{array}{c}\mathrm{N} \\
(\% \cdot \mathrm{w} / \mathrm{w})\end{array}$ & $\begin{array}{c}\mathrm{S} \\
(\% \cdot \mathrm{w} / \mathrm{w})\end{array}$ & $\begin{array}{c}\mathrm{P} \\
(\% \cdot \mathrm{w} / \mathrm{w})\end{array}$ \\
\hline Ungrafted Wool & 53.32 & 22.37 & 19.73 & 4.58 & 0.00 \\
\hline Grafted Wool & 50.43 & 24.73 & 19.40 & 3.52 & 1.92
\end{tabular}

3.8. SAXS.

SAXS was employed for crystallographic analysis of the VPA-grafted (GY=7.9\%) and ungrafted wool fabrics. As shown in Figure 8, the $\beta$-sheet structure of ungrafted wool exhibits two peaks at $2 \theta=9^{\circ}$ and $2 \theta=20^{\circ}$ [41]. Both crystallinity and crystallite size was calculated to be $38.0 \%$ and $9.6 \AA$ for the VPA-grafted wool and $31.4 \%$ and $6.2 \AA$ for the ungrafted fabric, respectively.

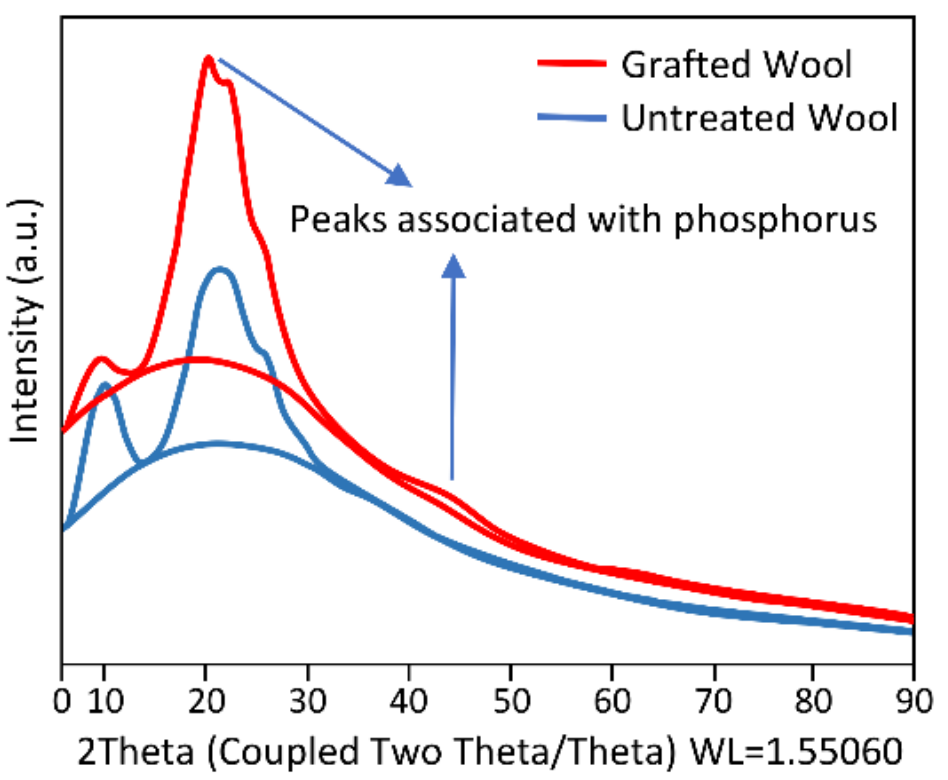

Figure 8. SAXS intensity curves of grafted and ungrafted wool fabrics.

Higher crystallinity and crystallite size and the appearance of two characteristic bands associated with phosphorus-containing carbon materials $\left(2 \theta=19^{\circ}\right.$ and $\left.2 \theta=45^{\circ}\right)$ [42] after grafting signify the addition of new crystals to wool. The peak at about $2 \theta=10^{\circ}$ corresponds to the hydrated crystalline structure of wool [43] and shows lower intensity for the grafted wool compared to the ungrafted sample. This may refer to the random rupture of some disulfide and/or hydrogen bonds caused by humidity, high temperature, and mechanical straining during grafting.

\section{9. $T G A$ and $T G D$.}

Thermal stability of the grafted $(G Y=7.9 \%)$ and ungrafted samples was investigated by Thermogravimetric analyses. TGA and TGD graphs of the grafted and ungrafted wool are shown in Figure 9. 


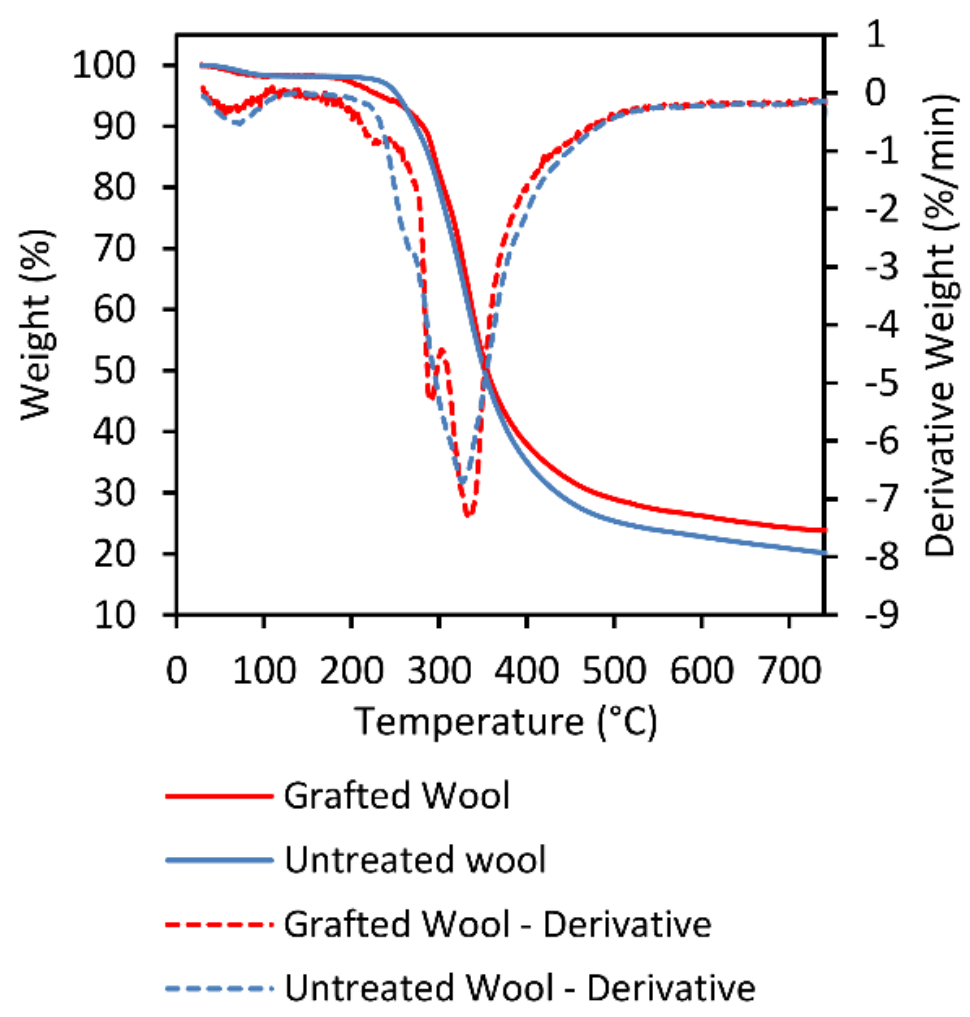

Figure 9. TGA and TGD graphs of grafted and ungrafted wool.

TGD graphs showed three and four distinctive weight loss stages for the ungrafted and grafted wool, respectively (Table 6). The first weight loss between $30{ }^{\circ} \mathrm{C}$ and $110{ }^{\circ} \mathrm{C}$ is attributed to the liberation of wool moisture content [41,44]. The second weight loss in TGA graphs of the grafted and ungrafted wool corresponds to the breakage of the cysteine bonds and the elimination of $\mathrm{H}_{2} \mathrm{~S}$ [45]. In addition to the first two weight-loss stages, the grafted wool TGD graph showed an extra peak at $292{ }^{\circ} \mathrm{C}$, denoting the degradation of newly formed phosphorus-containing crystals in wool. Pyrolysis of the polypeptide structure and the subsequent formation of smaller and volatile compounds, including $\mathrm{CO}_{2}, \mathrm{H}_{2} \mathrm{O}$, and $\mathrm{HCN}$, started at $273{ }^{\circ} \mathrm{C}$ for the ungrafted wool and $304{ }^{\circ} \mathrm{C}$ for the grafted specimen [46]. Grafted wool $(\mathrm{GY}=7.9 \%)$ showed a $3.86 \% \cdot \mathrm{w} / \mathrm{w}$ increase in char formation at $750{ }^{\circ} \mathrm{C}$ compared to the ungrafted wool. The higher remaining char ratio for the grafted wool indicates its higher flame-retardant performance compared to the ungrafted sample [19].

Table 6. TGA and TGD data of grafted and ungrafted wool.

\begin{tabular}{|c|c|c|c|c|}
\hline \multirow[b]{2}{*}{ Samples } & \multirow[b]{2}{*}{$\begin{array}{l}\text { Temperature } \\
\text { Range }\left({ }^{\circ} \mathrm{C}\right)\end{array}$} & \multirow{2}{*}{$\begin{array}{c}\text { TGD } \\
\text { Maximum Weight Loss } \\
\text { Rate }\left(\% \cdot \mathrm{min}^{-1}\right)\end{array}$} & \multicolumn{2}{|c|}{ TGA } \\
\hline & & & Weight Loss \% & $\begin{array}{c}\text { Residual Mass Ratio at } \\
750{ }^{\circ} \mathrm{C}(\%) \\
\end{array}$ \\
\hline \multirow{4}{*}{$\begin{array}{l}\text { Grafted } \\
\text { Wool }\end{array}$} & $30-110$ & 0.35 & 1.63 & \multirow{4}{*}{23.86} \\
\hline & $173-236$ & 0.86 & 3.29 & \\
\hline & $240-304$ & 5.32 & 14.15 & \\
\hline & $304-546$ & 7.32 & 53.16 & \\
\hline \multirow{3}{*}{ Ungrafted Wool } & $31-113$ & 0.53 & 1.71 & \multirow{3}{*}{20.00} \\
\hline & $261-273$ & 2.72 & 3.13 & \\
\hline & $273-530$ & 6.71 & 65.71 & \\
\hline
\end{tabular}

3.10. Ease of ignition for vertically oriented specimens.

Flame retardancy of both grafted and ungrafted samples was determined via ease of ignition test. Figure 10 shows ungrafted and grafted samples after exposure to a standard open 
flame for different periods. VPA-grafted specimens withstood the flame for significantly longer periods ( $7 \mathrm{~s}$ for $\mathrm{GY}=6 \%$ and $11 \mathrm{~s}$ for $\mathrm{GY}=8.1 \%$ ) than ungrafted fabric ( $3 \mathrm{~s}$ for $\mathrm{GY}=0 \%$ ). Moreover, grafted samples showed substantially higher rates of char formation and thus higher flame retardancy compared to the ungrafted specimen.
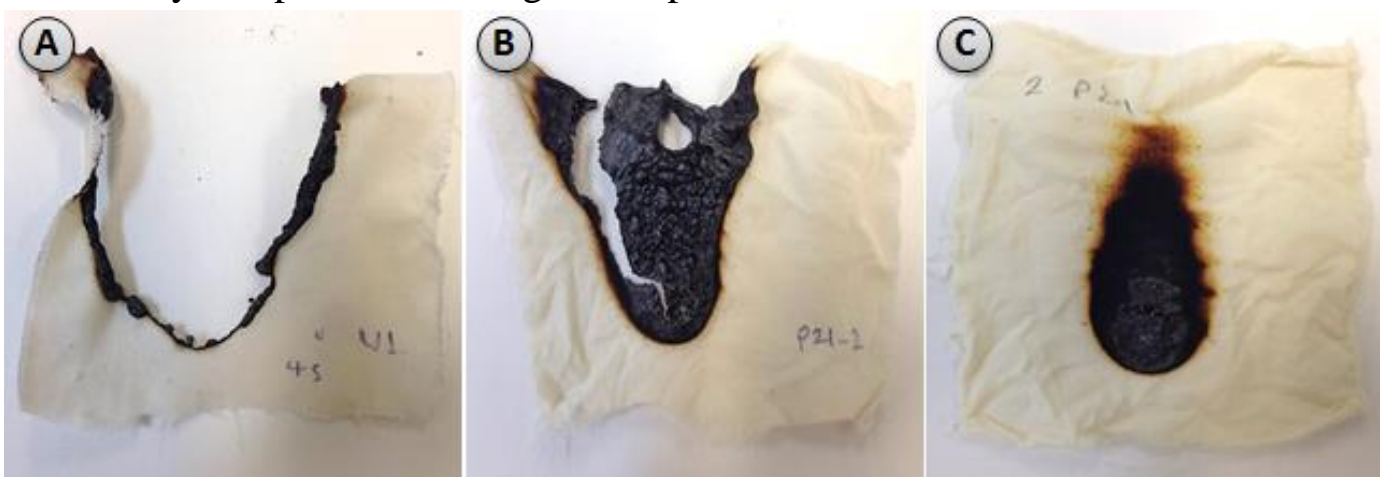

Figure 10. (A) Ungrafted wool after 3 s of flaming; (B) VPA-grafted wool $(G Y=6 \%)$ after 7 s of flaming; (C) VPA-grafted wool $(G Y=8.1 \%)$ after 9 s of flaming.

\subsection{Limiting oxygen index.}

Table 7 presents limiting-oxygen indices of VPA-grafted $(\mathrm{GY}=6 \%$ and $\mathrm{GY}=8.1 \%)$ and ungrafted wool samples. LOI values associated with the grafted wool were found to be substantially higher than that of the ungrafted wool. The elevation of LOI index after graft copolymerization of VPA signifies augmented flame retardancy associated with grafted samples compared to the ungrafted specimen.

Table 7. GY-LOI comparison for VPA-grafted and ungrafted wool.

\begin{tabular}{l|c|c} 
Sample & $G Y(\%)$ & LOI \\
\hline Ungrafted wool & 0 & 24.8 \\
\hline VPA-grafted wool & 6 & 31.2 \\
\hline VPA-grafted wool & 8.1 & 33.7
\end{tabular}

Table 8 shows the LOI values, fastness to washing, and halogenated/non-halogenated flame retardants used in the current study and other Zirpro® processes.

Table 8. Comparison between the current method and previous Zirpro® processes.

\begin{tabular}{l|c|c|c|c|c} 
FR compound & Process & LOI & Halogens & Wash Fastness & Reference \\
\hline Vinyl Phosphonic Acid & $\begin{array}{c}\text { Graft co- } \\
\text { polymerization }\end{array}$ & 33.7 & No & $\begin{array}{c}\text { Durable to standard } \\
\text { washing }\end{array}$ & $\begin{array}{c}\text { Current } \\
\text { study }\end{array}$ \\
\hline Zirconium Acetate & $\begin{array}{c}\text { Zirpro® Ionic } \\
\text { Exhaustion }\end{array}$ & 25.8 & No & Durable to dry-cleaning & {$[40,44]$} \\
\hline Zirconium Oxychloride & $\begin{array}{c}\text { Zirpro® Ionic } \\
\text { Exhaustion }\end{array}$ & 31.9 & Yes & Durable to dry-cleaning & {$[40,47]$} \\
\hline $\begin{array}{l}\text { Titanium Hexafluoride } \\
\text { Complexes }\end{array}$ & $\begin{array}{c}\text { Zirpro® Ionic } \\
\text { Exhaustion }\end{array}$ & $\begin{array}{c}31- \\
32\end{array}$ & Yes & Durable to dry-cleaning & {$[40,48]$}
\end{tabular}

\subsection{Limitations of the study.}

FR properties could also be evaluated using forced combustion technology. Cone calorimetry tests may be conducted in the future to gather data regarding the ignition time, mass loss, combustion products, heat release rate, etc. TG analysis (in air medium) of the smoke during tests will be within the scope of future publication. 


\section{Conclusions}

The successful graft co-polymerization of the vinyl phosphonic acid onto wool fabric was confirmed via FTIR, ${ }^{31}$ P Solid-state NMR, SAXS, SEM, and SEM-EDX. The maximum yield of graft co-polymerization $(\mathrm{GY}=8.1 \%)$ was achieved via mathematical modeling and optimization of grafting parameters. Thermogravimetric analyses showed about a $4 \%$ increase in the remaining char ratio at $750{ }^{\circ} \mathrm{C}$ as well as superior thermal resistance at temperatures above $250{ }^{\circ} \mathrm{C}$ for the VPA-grafted wool $(\mathrm{GY}=7.9 \%)$ compared to the untreated fabric. The ease of ignition test showed significant improvement in flame retardancy for the grafted wool $(\mathrm{GY}=8.1 \%)$, which withstood the flame $8 \mathrm{~s}$ longer than the untreated sample before ignition. Although the evaluation of physical properties was not within the scope of our research, the dimensional stability of the fabrics after grafting was found to be more than $95 \%$.

In summary, the successful formation of new covalent bonds between the green flameretardant compound (VPA) and wool, the durability of the applied finish, ease of processing, environmental friendliness, and superior flame-retardant properties make this process a green and suitable replacement for the conventional Zirpro® processes.

\section{Funding}

This research received no external funding.

\section{Acknowledgments}

The authors would like to express their gratitude to Dr. Matthew Field from the RMIT Microscopy and Microanalysis Facility (RMMF) and Mr. Robert Brkljaca from the RMIT NMR Facility for their technical support during this research.

\section{Conflicts of Interest}

The authors declare no conflict of interest.

\section{References}

1. Liang, S.; Neisius, N.M.; Gaan, S. Recent Developments in Flame Retardant Polymeric Coatings. Prog. Org. Coat. 2013, 76, 1642-1665, https://doi.org/10.1016/j.porgcoat.2013.07.014.

2. Levchik, S.V.; Weil, E.D. A Review of Recent Progress in Phosphorus-based Flame Retardants. J. Fire Sci. 2006, 24, 345-364, http://doi.org/10.1177/0734904106068426.

3. Horrocks, A.R.; Price, D., (Eds.) Fire Retardant Materials. Woodhead Publishing and CRC Press LLC: 2001.

4. Basak, S.; Samanta, K.; Chattopadhyay, S.K.; Pandit, P.; Maiti, S. Green Fire Retardant Finishing and Combined Dyeing of Proteinous Wool Fabric. Color. Technol. 2016, 132, 135-143, https://doi.org/10.1111/cote.12200.

5. Taheri, M.; Maleknia, L.; Ghamsari, N.A.; Almasian, A.; Fard, G.C. Effect of zirconium dioxide nanoparticles as a mordant on properties of wool with thyme: dyeing, flammability and antibacterial. Oriental Journal of Chemistry 2015, 31, 85, http://doi.org/10.13005/ojc/310109.

6. Jose, S.; Shanmugam, N.; Das, S.; Kumar, A.; Pandit, P. Coating of lightweight wool fabric with nano clay for fire retardancy. J. Text. Inst. 2019, 110, 764-770, https://doi.org/10.1080/00405000.2018.1516529.

7. Sykam, K.; Försth, M.; Sas, G.; Restás, Á.; Das, O. Phytic acid: A bio-based flame retardant for cotton and wool fabrics. Industrial Crops and Products 2021, 164, 113349, https://doi.org/10.1016/j.indcrop.2021.113349.

8. Kaynak, E.; Üreyen, M.E.; Koparal, A.S. Halogen free flame retardant finishing of wool and wool rich fabrics for aircraft seats. Materials Today: Proceedings 2020, 31, S258-S262, https://doi.org/10.1016/j.matpr.2019.11.284. 
9. Cheng, X.-W.; Zhang, W.; Wu, Y.-X.; Ma, Y.-D.; Xu, J.-T.; Guan, J.-P. Borate functionalized caramel as effective intumescent flame retardant for wool fabric. Polym. Degrad. Stabil. 2021, 186, 109469, https://doi.org/10.1016/j.polymdegradstab.2020.109469.

10. Mathur, P.; Sheikh, J.N.; Sen, K. Durable flame-retardant wool using sulphamic acid. Polym. Degrad. Stabil. 2020, 174, 109101, https://doi.org/10.1016/j.polymdegradstab.2020.109101.

11. Mohd, Y. A Review on Flame Retardant Textile Finishing: Current and Future Trends. Current Smart Materials 2018, 3, 99-108, http://dx.doi.org/10.2174/2405465803666180703110858.

12. Morgan, A.B.; Wilkie, C.A. The Non-Halogenated Flame Retardant Handbook; John Wiley \& Sons: 2014.

13. Vorkamp, K.; Balmer, J.; Hung, H.; Letcher, R.J.; Rigét, F.F.; de Wit, C.A. Current-use halogenated and organophosphorous flame retardants: A review of their presence in Arctic ecosystems. Emerging Contaminants 2019, 5, 179-200, https://doi.org/10.1016/j.emcon.2019.05.004.

14. Green, J. A Review of Phosphorus-Containing Flame Retardants. J. Fire Sci. 1992, 10, 470-487, https://doi.org/10.1177/073490419201000602.

15. Cheng, X.-W.; Guan, J.-P.; Yang, X.-H.; Tang, R.-C.; Yao, F. A Bio-Resourced Phytic Acid/Chitosan Polyelectrolyte Complex for the Flame Retardant Treatment of Wool Fabric. J. Clean. Prod. 2019, 223, 342-349, https://doi.org/10.1016/j.jclepro.2019.03.157.

16. Jiang, W.; Li, J.-F.; Li, Z.-Y.; Zhang, X.-Y.; Jin, F.-L.; Park, S.-J. A novel synthesis of ditrimethylolpropane biphosphoramide diethyleneamine as flame retardant and antistatic textiles. Korean Journal of Chemical Engineering 2021, 38, 872-884, 10.1007/s11814-021-0744-1.

17. Liu, Y.; Guo, Y.; Ren, Y.; Wang, Y.; Guo, X.; Liu, X. Phosphorylation of sodium copper chlorophyll enables color-fasten and durable flame retardant wool fibers. Polym. Degrad. Stabil. 2020, 179, 109286, https://doi.org/10.1016/j.polymdegradstab.2020.109286.

18. Hörold, S. Chapter 6 - Phosphorus-based and Intumescent Flame Retardants. In Polymer Green Flame Retardants, Papaspyrides, C.D., Kiliaris, P., Eds.; Elsevier: Amsterdam, 2014; pp. 221-254, https://doi.org/10.1016/B978-0-444-53808-6.00006-8.

19. Mohaddes, F.; Wang, L.; Shanks, R.A.; Fergusson, S.M. Elevation of Charring Level of Polyamide-6,6 Films via Ionic Introduction of Phosphoric Acid and Boric Acid Esters. Green Chem Lett Rev 2014, 7 , 184-190, https://doi.org/10.1080/17518253.2014.922624.

20. El Garf, S.A.; El Mehy, A.A.; Abou Steet, Y.Z.; Morsi, A.M. Phosphorylation of Nylon 6. Text. Res. J. 1978, 48, 550-553, https://doi.org/10.1177/004051757804800910.

21. Yang, H.; Yang, C.Q.; He, Q. The Bonding of a Hydroxy-Functional Organophosphorus Oligomer to Nylon Fabric Using the Formaldehyde Derivatives of Urea and Melamine as the Bonding Agents. Polym. Degrad. Stabil. 2009, 94, 1023-1031, https://doi.org/10.1016/j.polymdegradstab.2009.02.008.

22. Levchik, S.V.; Levchik, G.F.; Camino, G.; Costa, L. Mechanism of Action of Phosphorus-Based Flame Retardants in Nylon 6. II. Ammonium Polyphosphate/Talc. J. Fire Sci. 1995, 13, 43-58, https://doi.org/10.1177/073490419501300103.

23. Levchik, S.V.; Levchik, G.F.; Camino, G.; Costa, L.; Lesnikovich, A.I. Mechanism of Action of Phosphorus-based Flame Retardants in Nylon 6. III. Ammonium Polyphosphate/Manganese Dioxide. Fire Mater. 1996, 20, 183-190, https://doi.org/10.1002/(sici)1099-1018(199607)20:4<183::aidfam574>3.0.co;2-w.

24. Opwis, K.; Wego, A.; Bahners, T.; Schollmeyer, E. Permanent Flame Retardant Finishing of Textile Materials by a Photochemical Immobilization of Vinyl Phosphonic Acid. Polym. Degrad. Stabil. 2011, 96, 393-395, https://doi.org/10.1016/j.polymdegradstab.2010.02.022.

25. Stannett, V.; Araki, K.; A. Gervasi, J.; W. McLeskey, S. Radiation Grafting of Vinyl Monomers to Wool. Part I. J. Polym. Sci. A Gen. Pap. 1965, 3, 3763-3779, https://doi.org/10.1002/pol.1965.100031108.

26. Walter Dürsch, K.; Jiirgen Grosse, E.-L.; Werner Gohla, N.; Engelhardt, F.; Riegel, U. Porcess for the Preparation of Copolymers of Vinylphosphonic Acid and (METH) Acrylic acid in Aqueous Solution US4749758A, 1988.

27. Giri, G.; Samal, R.K. Grafting onto Wool Fibers: Graft Copolymerization of Methyl Methacrylate onto Wool Fibers Initiated by $\mathrm{KHSO}_{5} / \mathrm{Fe}(\mathrm{III})$ Couple. J Appl Polym Sci 1991, 42, 2371-2375, https://doi.org/10.1002/app.1991.070420830.

28. Mosleh, S. Chemical Grafting of 2-Ethyl Methacrylate Phosphoric Acid onto Nylon 6 Fabric. J Appl Polym Sci 2000, 77, 1357-1361, https://doi.org/10.1002/1097-4628(20000808)77:6<1357::aidapp22>3.0.co;2-r.

29. ASTM International. Standard Test Method for Measuring the Minimum Oxygen Concentration to Support Candle-Like Combustion of Plastics (Oxygen Index). 2013, D2863-13, 1-14, https://doi.org/10.1520/D2863-13.

30. Bhattacharya, A.; Misra, B.N. Grafting: A Versatile Means to Modify Polymers: Techniques, Factors and Applications. Prog. Polym. Sci. 2004, 29, 767-814, http://dx.doi.org/10.1016/j.progpolymsci.2004.05.002. 
31. Lipp-Symonowicz, B.; Sztajnowski, S.; Kułak, A. IR Spectroscopy as a Possible Method of Analysing Fibre Structures and Their Changes Under Various Impacts. In Infrared Radiation, Morozhenko, V., Ed.; InTech: 2012; pp. 27-40, https://doi.org/10.5772/37155.

32. Pavia, D.L.; Lampman, G.M.; Kriz, G.S. Introduction to Spectroscopy: A Guide for Students of Organic Chemistry, 2nd ed.; Harcourt Brace College Publishers: Fort Worth, 1996.

33. Zenobi, M.C.; Luengo, C.V.; Avena, M.J.; Rueda, E.H. An ATR-FTIR Study of Different Phosphonic Acids in Aqueous Solution. Spectrochim. Acta A Mol. Biomol. Spectrosc. 2008, 70, 270-276, https://doi.org/10.1016/j.saa.2007.07.043.

34. Onizuka, H.; Kato, M.; Shimura, T.; Sakamoto, W.; Yogo, T. Synthesis of Proton Conductive InorganicOrganic Hybrid Membranes Through Copolymerization of Dimethylethoxyvinylsilane with Vinylphosphonic Acid. J Solgel Sci Technol 2008, 46, 107-115, https://doi.org/10.1007/s10971-0081704-5.

35. Illy, N.; Couture, G.; Auvergne, R.; Caillol, S.; David, G.; Boutevin, B. New Prospects for the Synthesis of N-Alkyl Phosphonate/Phosphonic Acid-Bearing Oligo-Chitosan. RSC Adv. 2014, 4, 24042-24052, https://doi.org/10.1039/C4RA02501F.

36. Kolthoff, I.M.; Miller, I.K. The Chemistry of Persulfate. I. The Kinetics and Mechanism of the Decomposition of the Persulfate Ion in Aqueous Medium ${ }^{1}$. J. Am. Chem. Soc. 1951, 73, 3055-3059, http://doi.org/10.1021/ja01151a024.

37. Kamat, S.S.; Williams, H.J.; Raushel, F.M. Intermediates in the Transformation of Phosphonates to Phosphate by Bacteria. Nature 2011, 480, 570-573, http://dx.doi.org/10.1038/nature10622.

38. Cade-Menun, B.J. Characterizing Phosphorus in Environmental and Agricultural Samples by $31 \mathrm{P}$ Nuclear Magnetic Resonance Spectroscopy. Talanta 2005, 66, 359-371, https://doi.org/10.1016/j.talanta.2004.12.024.

39. Hutchinson, S.; Evans, D.; Corino, G.; Kattenbelt, J. An Evaluation of the Action of Thioesterases on the Surface of Wool. Enzyme Microb. Technol. 2007, 40, 1794-1800, http://dx.doi.org/10.1016/j.enzmictec.2007.01.016.

40. Horrocks, A.R. Flame Retardant Challenges for Textiles and Fibres: New Chemistry Versus Innovatory Solutions. Polym. Stabil. https://doi.org/10.1016/j.polymdegradstab.2010.03.036.

41. Wang, K.; Li, R.; Ma, J.H.; Jian, Y.K.; Che, J.N. Extracting Keratin from Wool by using L-Cysteine. Green Chem. 2016, 18, 476-481, https://doi.org/10.1039/C5GC01254F.

42. Viswanathan, B.; Murugesan, S.; Ariharan, A.; Lakhi, K.S. Hetero Atom Substituted Carbon-Potential Hydrogen Storage Materials. Advanced Porous Materials 2013, 1, 122-128, https://doi.org/10.1166/apm.2013.1008.

43. Xu, W.; Ke, G.; Wu, J.; Wang, X. Modification of Wool Fiber using Steam Explosion. Eur. Polym. J. 2006, 42, 2168-2173, http://dx.doi.org/10.1016/j.eurpolymj.2006.03.026.

44. Forouharshad, M.; Montazer, M.; Moghadam, M.B.; Saligheh, O. Preparation of Flame Retardant Wool using Zirconium Acetate Optimized by CCD. Thermochim. Acta 2011, 520, 134-138, https://doi.org/10.1016/j.tca.2011.03.029.

45. Idris, A.; Vijayaraghavan, R.; Rana, U.A.; Patti, A.F.; MacFarlane, D.R. Dissolution and Regeneration of Wool Keratin in Ionic Liquids. Green Chem. 2014, 16, 2857-2864, https://doi.org/10.1039/C4GC00213J.

46. Davies, P.J.; Horrocks, A.R.; Miraftab, M. Scanning Electron Microscopic Studies of Wool/Intumescent Char Formation. Polym. Int. 2000, 49, 1125-1132, https://doi.org/10.1002/10970126(200010)49:10<1125::AID-PI489>3.0.CO;2-B.

47. Forouharshad, M.; Montazer, M.; Moghadam, M.B.; Saligheh, O. Flame Retardant Wool using Zirconium Oxychloride in Various Acidic Media Optimized by RSM. Thermochim. Acta 2011, 516, 2934, https://doi.org/10.1016/j.tca.2011.01.007.

48. Martini, P.; Spearpoint, M.J.; Ingham, P.E. Low-Cost Wool-Based Fire Blocking Inter-liners for Upholstered Furniture. Fire Saf. J. 2010, 45, 238-248, https://doi.org/10.1016/j.firesaf.2010.03.005. 